\title{
The Effect Analysis of Emotional Intelligence and Work Environment on Employee Performance with Organizational Commitment as Intervening Variables in PT Berkat Bima Sentana
}

\author{
Yusuf Ronny Edward ${ }^{1}$, Kuras Purba ${ }^{2}$ \\ ${ }^{1,2}$ Postgraduate Program in Universitas Prima Indonesia, Indonesia \\ yusufronny77@gmail.com
}

\begin{abstract}
This study aims to determine the effect of emotional intelligence and work environment on employee performance through organizational commitment at PT. Berkat Bima Sentana. This research was conducted at PT. Berkat Bima Sentana which lasts for 6 (six) months, starting from August 2019 to January 2020. This study uses a quantitative associative method with structural equation modeling (SEM) analysis tools. The sampling technique used is proportional stratified random sampling using the Slovin formula. The respondents of this study were employees at PT. Berkat Bima Sentana as many as 98 people. The instrument used was a questionnaire to collect data on variables of emotional intelligence, work environment, organizational commitment and employee performance variables. Descriptive analysis results for the variables of emotional intelligence, work environment, organizational commitment and employee performance at PT. Berkat Bima Sentana, it is in the good category. Based on SEM analysis, emotional intelligence and work environment have a positive and significant impact on employee performance through organizational commitment at PT. Berkat Bima Sentana. Contributions from the variables of emotional intelligence, work environment and organizational commitment explain variable employee performance by 0.818 or $81.8 \%$. The remaining 0.182 or $18.2 \%$ is influenced by other independent variables not examined in this study.
\end{abstract}

Keywords

emotional intelligence, work environment; organizational cormitment; performance

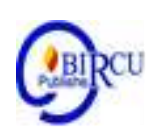

\section{Introduction}

Every company to be able to develop and progress always requires employees who have reliable performance. To realize reliable employee performance, it takes variables that influence so that employees are triggered to improve their performance. Among these variables can be felt that the satisfaction obtained while working and the culture of the organization has a good role in the growth and development of employee performance. Where job satisfaction is a pleasant and loving emotional attitude to the worker. This attitude is reflected by work morale, discipline, and work performance. (Hasibuan, 2013). Meanwhile, according to Siagian in Syardianah (2020), job satisfaction is a person's perspective both positive and negative about their work.

Electrical energy is one of the main needs for regions where the economy is growing, increasing demand for electricity supply for the community is in line with the growing number of people and the rapid development carried out by the government today requires serious attention from all parties, especially the government. 
PT. Berkat Bima Sentana, it is one of the largest diesel power generation (PLTD) companies in Indonesia with an electricity production capacity of 120 Megawatts. Currently PT. Berkat Bima Sentana, is one of the partners of PT. Perusahaan Listrik Negara Persero to meet the electricity needs of the people of North Sumatra in general, the city of Medan in particular.

Development and growth of PT. Berkat Bima Sentana itself, of course, is supported by the performance of its employees. Performance becomes the real foundation in an organization because if there is no performance then the goals of the organization cannot be achieved. The competitive advantage of an organization is largely determined by performance, because basically individual performance affects the performance of a team or work group and ultimately affects overall organizational performance (Ronny and Susanti, 2019).

Performance appraisal is one of the functions of human resource management, so it should be done properly. Without performance appraisal, management will certainly find it difficult to determine, for example, how much salary or bonuses, or other appropriate welfare given to employees (Ronny, 2020).

To measure the performance of employees at PT. Berkat Bima Sentana, he conducts a performance appraisal every semester, in which the semester one assessment starts from January to June while the second semester assessment starts from July to December.

Table 1. Performance Results of PT Berkat Bima Sentana Semester II Year 2019

\begin{tabular}{|l|c|c|}
\hline \multicolumn{1}{|c|}{ Score } & Number of Employees (People) & Percentage $\mathbf{( \% )}$ \\
\hline A $(\mathbf{8 1}-\mathbf{1 0 0})$ & 8 & 6 \\
\hline B $(\mathbf{7 1}-\mathbf{8 0})$ & 38 & 29 \\
\hline C $(\mathbf{5 6}-\mathbf{7 0})$ & 53 & 41 \\
\hline D (45 - 55) & 28 & 22 \\
\hline E (01 - 44) & 2 & 2 \\
\hline
\end{tabular}

Source: Data obtained by researchers, 2019

Based on the results of the assessment shows that the performance of employees at PT. Berkat Bima Sentana, it's still not optimal.

One factor that is considered to affect employee performance is organizational commitment. Where employees who have high organizational commitment will tend to have high performance (Luter, 2013). The factors that can affect organizational commitment are emotional intelligence research conducted by Mutimma, 2016 shows that emotional intelligence has a positive and significant effect on organizational commitment. In addition to emotional intelligence, the work environment is also one of the factors that can influence the level of organizational commitment (Wowor et al., 2016).

Based on the description above, the researchers conducted a research entitled "Analysis of the Effects of Emotional Intelligence, Work Environment on Employee Performance with Organizational Commitment at PT. Berkat Bima Sentana." 


\section{Review of Literatures}

\subsection{Emotional Intelligence}

According to Hasibuan (2005) ability / intelligence shows the potential of people to carry out work. According to Kreitner and Kinicki (2003), intelligence is the capacity to think reason and solve constructive problems.

Lazarus in Kreitner and Kinicki (2003) states that emotions are complex and patterned reactions of organisms about how we think about what we do throughout life to survive and enliven life and to achieve what we want for ourselves.

Goleman (2005), explains that: "Emotional skills are learning outcomes skills that are based on emotional intelligence and therefore produce prominent performance in work. Goleman (2005) further states: "Emotional intelligence refers to the ability to recognize our own feelings and the feelings of others, the ability to motivate ourselves, and the ability to manage emotions well in ourselves and in relationships with others."

From some of the above understanding, it can be concluded that emotional intelligence can be interpreted as the ability to recognize, manage and express appropriately, including to motivate yourself, recognize the emotions of others, and foster relationships with others.

Dimensions of emotional intelligence according to Goleman (2005) are as follows:

1. Self-recognition, meaning knowing the inner state, things that are preferred, and intuition. Competence in the first dimension is recognizing one's own emotions, knowing one's strengths and limitations, and belief in one's own abilities.

2. Self-control, which means managing the situation within oneself and one's own resources. This second dimension of competence is to hold negative emotions and impulses, maintain the norms of honesty and integrity, be responsible for personal performance, flexible to change, and open to new ideas and information.

3. Motivation, which means encouragement that guides or assists the achievement of goals or objectives. The third dimension of competence is the drive to be better, to adjust to the goals of the group or organization, readiness to take advantage of opportunities, and persistence in fighting for failures and obstacles.

4. Empathy, which is an awareness of people's feelings, interests, and concerns. The fourth dimension consists of understanding others competencies, developing others, customer service, creating opportunities through association with various people, reading the relationship between the emotional state and the strength of a group's relationships.

5. Social skills, which means skills in arousing the responses desired by others. Among them are the ability of persuasion, listening openly and giving clear messages, the ability to resolve opinions, the spirit of leadership, collaboration and cooperation, and team building.

\subsection{Work Environment}

According to Sedarmayanti (2011), the work environment is the overall tools and materials faced by the surrounding environment in which a person works, his work methods, and work arrangements both as individuals and as groups.

According to Nitisemito (2009), the work environment is anything that exists around workers and that can influence themselves in carrying out the tasks that they carry or are responsible for.

Based on this definition, it can be stated that the work environment is a place where employees carry out their duties and is a working condition of employees who live and work together and continue continuously and produce memorable actions in carrying out each task and work. 
into 2 viz

The dimensions of the work environment according to Sedarmayanti (2011) are divided

1. Physical work environment, all physical forms that are around the workplace that can affect employees directly or indirectly

2. Non-physical work environment, all conditions that occur relating to work relationships, both relationships with superiors and fellow co-workers, or relationships with subordinates.

\subsection{Organizational Commitment}

According to Robbins and Judge (2015), organizational commitment is the level at which a worker identifies an organization, its goals and hopes to remain a member. Meanwhile according to Kaswan (2012), organizational commitment is a measure of the willingness of employees to stay with a company in the future.

According to Mayer and Allen in Kaswan (2012), organizational commitment consists of three dimensions, namely:

1. Affective Commitments

Show the strong emotional desire of employees to adapt to existing values so that their goals and desires to remain in the organization can be realized. Affective commitment can arise in an employee because of: individual characteristics, organizational structure characteristics, significance of tasks, various expertise, feedback from leaders and involvement in management. Age and length of service in an organization are very positively related to affective commitment. Employees who have affective commitment will tend to remain in an organization because they fully trust the mission carried out by the organization.

2. Continuation Commitment

This is a commitment that is based on one's concern about the loss that has been obtained so far in the organization, such as salary, facilities and others. Matters that cause a continuing commitment include age, position and various facilities and various benefits received. This commitment will decrease if there is a reduction in various facilities and welfare obtained by employees.

3. Normative Commitment

Demonstrates employee moral responsibility to remain in the organization. The cause of this commitment is a social demand that is the result of a person's experience in interacting with others or the emergence of permanent adherence to a role model or owner of an organization due to retribution, social, cultural or religious respect. Individuals with high normative commitment will remain in the organization because they feel an obligation or task.

\subsection{The Performance}

A person's performance is closely related to the results of work concerning quality, quantity and timeliness. Performance also means the comparison of work results achieved by employees with predetermined standards (Ronny, 2020).

According to Ivancevich, Konopaske and Matteson (Busro, 2018) that performance shows the ability and skills of workers. Opinions emphasize the competence of human resources possessed by organizations, ranging from the ability of employees' cognition, affection, and psychomotor.

According to Kaswan (2012), there are six criteria that are used as a basis for assessing performance, including: 


\section{Quality.}

How far / well the process or outcome of carrying out an activity approaches perfection, in terms of conformity with the ideal way of carrying out an activity or meeting the desired objectives of an activity.

2. Quantity.

The amount produced is expressed in terms of dollars / rupiah, the number of units, or the number of activity cycles that have been completed.

3. Timeliness.

4. How far / whether an activity is completed, or the results produced, at the earliest time desired from the point of view of coordinating with other outputs or maximizing the time available for other activities.

4. Cost effectiveness.

To what extent / good organizational resources (eg human, monetary, technological, and material) are maximized in terms of obtaining the highest profit or reduction in losses from each unit, or examples of resource use.

5. The need for supervision.

To what extent / is an employee able to carry out work functions without having to ask for supervisory assistance or require supervision intervention to prevent adverse results.

\section{Research Methods}

This research was conducted at PT. Thanks to Bima Kencana, located on Jalan Pulau Sicanang, Kec. Medan Belawan, North Sumatra. This type of research is associative research. According to Sugiyono (2014) the definition of associative quantitative research methods is research that aims to determine the effect or also the relationship between two or more variables.

In this study, associative research methods are used to determine the magnitude of influence between one variable with another variable. The population in this study were all employees at PT. Berkat Bima Sentana in 2019 there were 135 employees. Samples were taken based on probability sampling techniques, namely proportionate random sampling using the Slovin formula so that a sample of 98 employees was obtained.

Collecting data in this study by making a list of questions in the form of questionnaires using a Likert scale with a scale of 1 (strongly disagree) and a scale of 5 (strongly agree) then after being filled out completely then returning it to the researcher with exogenous latent variables $(\xi 1 / \mathrm{X} 1)$ is emotional intelligence, exogenous latent variable ( $(\xi 2 / \mathrm{X} 2)$ is work environment, endogenous latent variable $(\eta 1 / Z)$ is organizational commitment and endogenous latent variable $(\eta 2 / Y)$ is employee performance. The model of this research is as follows:

The research model is as follows:

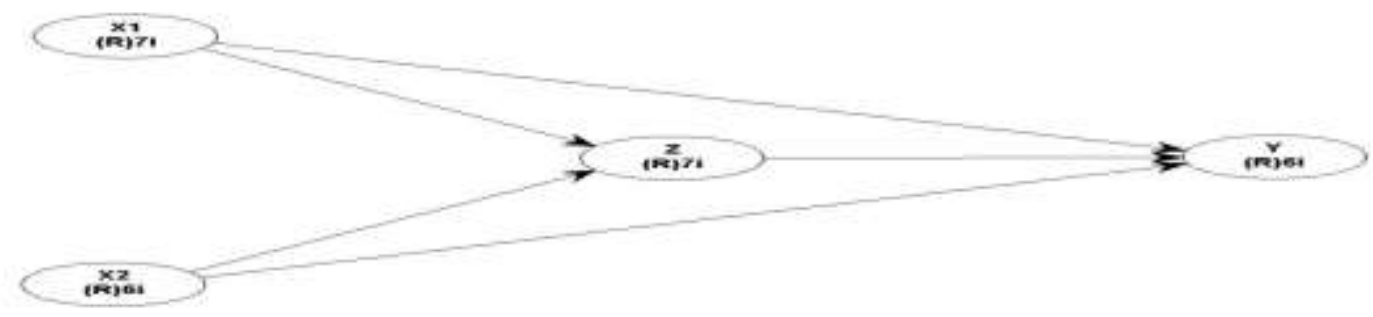

Figure 1. Research Model 
The data analysis tool uses structural equation modeling (SEM) with the WarpPls 7.0 application program, where before the data was processed the questionnaire was given to 30 employees of PT. Berkat Bima Sentana, the respondents outside were assigned to test the validity and reliability of the research questionnaire. If the questionnaire is valid and reliable, it will evaluate the model by evaluating the outer model and evaluating the inner model and continuing with the hypothesis test

\section{Discussion}

PT. Berkat Bima Sentana is a company engaged in the field of diesel power plants (PLTD) founded in 2012 headquartered in Medan City, North Sumatra Province. Establishment of PT. Berkat Bima Sentana, there is a background of increasing demand for electricity in northern Sumatra in general, so that it is expected to reduce the deficit in electricity, especially in the city of Medan.

Collaborate with the State Electricity Company (PT. PLN Persero) through the EPC (Engineering, Procurement and Construction) contract. Diesel power plant PT. Berkat Bima Sentana with a capacity of 120 Mega Watt (MW) located on Belawan Sicanang Island, Medan City began operating in 2014.

With the operation of PT. Berkat Bima Sentana at the end of 2014, it had a very positive impact in reducing the deficit in electricity, especially in the city of Medan.

Inferential statistical analysis using structural equation modeling with the WarpPLS 7.0 application program consists of analysis of the measurement model (outter model) and structural model analysis (inner model).

Analysis of the measurement model (outter model) consists of indicators of reliability, internal consistency reliability, convergent validity and discriminant validity (Latan and Ghozali, 2016). The measure used to measure the reliability indicator is by looking at the loading factor value of each construct indicator. The rule of thumb used to assess the loading factor is that it must be greater than 0.7 for confirmatory research (Latan and Ghozali, 2016). The loading factor values contained in this study can be seen in table 2, as follows:

Table 2. Loading Factor and Cross Loading

\begin{tabular}{ccccc}
\hline & $\mathbf{X 1}$ & $\mathbf{X 2}$ & $\mathbf{Z}$ & $\mathbf{Y}$ \\
\hline $\mathrm{X} 11$ & $(0.719)$ & 0.215 & 0.432 & 0.462 \\
\hline $\mathrm{X} 12$ & $(0.719)$ & 0.397 & 0.514 & 0.580 \\
\hline $\mathrm{X} 13$ & $(0.746)$ & 0.356 & 0.426 & 0.505 \\
\hline $\mathrm{X} 14$ & $(0.728)$ & 0.287 & 0.327 & 0.506 \\
\hline $\mathrm{X} 15$ & $(0.737)$ & 0.311 & 0.400 & 0.523 \\
\hline $\mathrm{X} 16$ & $(0.706)$ & 0.291 & 0.386 & 0.493 \\
\hline $\mathrm{X} 17$ & $(0.734)$ & 0.218 & 0.345 & 0.457 \\
\hline $\mathrm{X} 21$ & 0.333 & $(0.766)$ & 0.466 & 0.589 \\
\hline $\mathrm{X} 22$ & 0.288 & $(0.806)$ & 0.494 & 0.606 \\
\hline $\mathrm{X} 23$ & 0.328 & $(0.767)$ & 0.425 & 0.540 \\
\hline $\mathrm{X} 24$ & 0.300 & $(0.773)$ & 0.368 & 0.607 \\
\hline $\mathrm{X} 25$ & 0.257 & $(0.758)$ & 0.390 & 0.545 \\
\hline $\mathrm{X} 26$ & 0.391 & $(0.785)$ & 0.552 & 0.643 \\
\hline Z1 & 0.403 & 0.421 & $(0.747)$ & 0.593 \\
\hline Z2 & 0.315 & 0.469 & $(0.726)$ & 0.530 \\
\hline Z3 & 0.466 & 0.505 & $(0.810)$ & 0.662 \\
\hline
\end{tabular}




\begin{tabular}{ccccc}
\hline Z4 & 0.432 & 0.416 & $(0.801)$ & 0.570 \\
\hline Z5 & 0.504 & 0.386 & $(0.818)$ & 0.615 \\
\hline Z6 & 0.504 & 0.485 & $(0.817)$ & 0.663 \\
\hline Z7 & 0.434 & 0.521 & $(0.803)$ & 0.646 \\
\hline Y1 & 0.451 & 0.594 & 0.609 & $(0.770)$ \\
\hline Y2 & 0.563 & 0.565 & 0.647 & $(0.795)$ \\
\hline Y3 & 0.584 & 0.528 & 0.527 & $(0.733)$ \\
\hline Y4 & 0.568 & 0.528 & 0.565 & $(0.781)$ \\
\hline Y5 & 0.524 & 0.691 & 0.599 & $(0.806)$ \\
\hline Y6 & 0.496 & 0.579 & 0.622 & $(0.708)$ \\
\hline
\end{tabular}

Source: Research Results, 2020 (Data processed)

Based on table 2 it appears that the value of the loading factor of each variable is greater than 0.7 , thus the research model has fulfilled the reliability indicator requirements.

Internal consistency reliability assessment is done by looking at the magnitude of the composite reliability value which must be greater than 0.7 for research that is conimatory, while the convergent validity assessment is done by looking at the value of Average Variance Extracted (AVE), where if the AVE value obtained is greater than 0.50, then the indicators used have met the convergent validity (Latan and Ghozali, 2016). The composite reliability and AVE values obtained in this study can be seen in the following figure 2 :

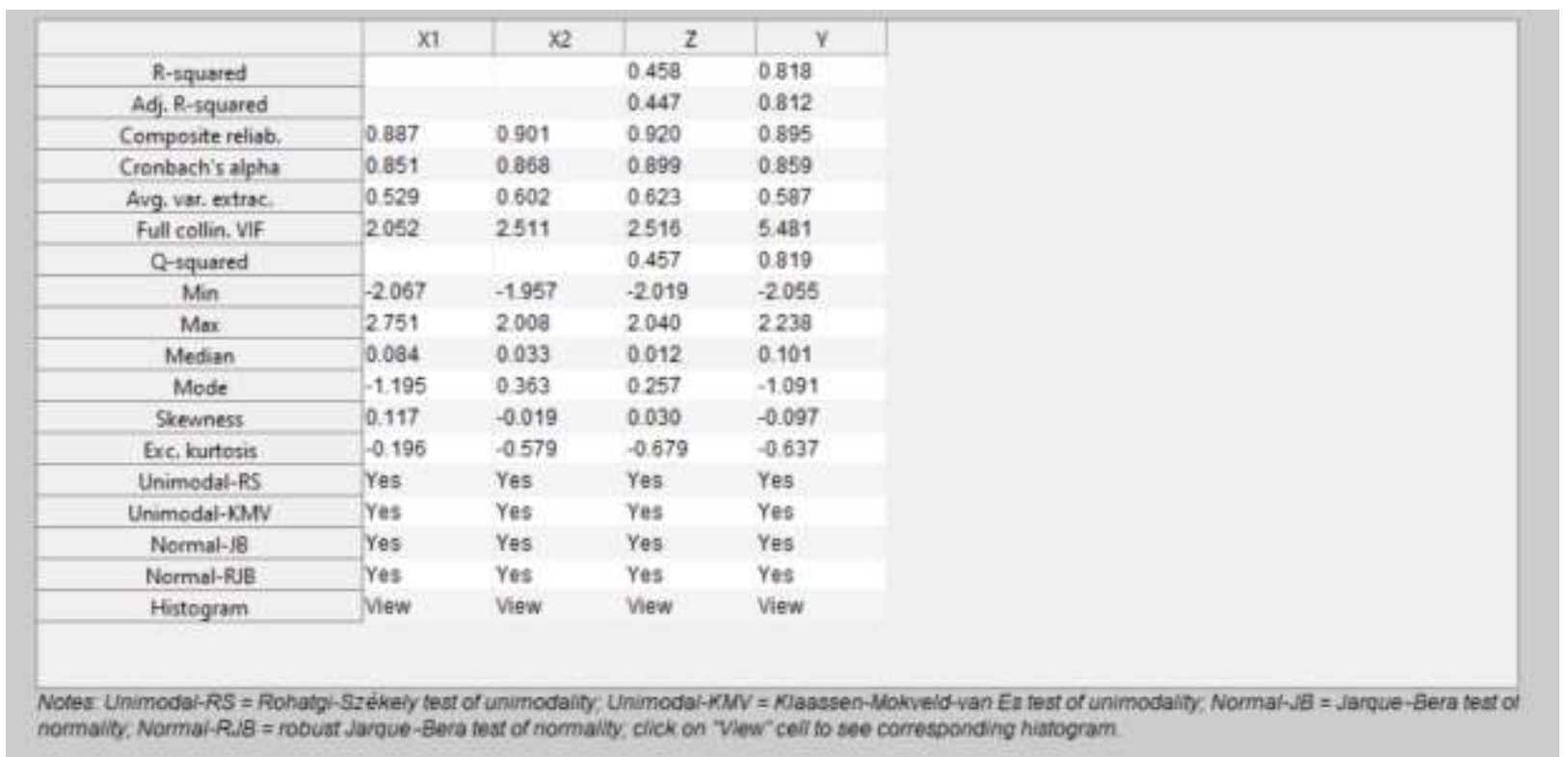

Figure 2. AVE and Composite Reliability

Source: Research Results, 2020 (Data Processed)

Based on Figure 2, it can be seen that the composite reliability value for all variables is greater than 0.7 and the AVE value for each variable is above 0.50 so that it can be stated that this research model has fulfilled the assessment of internal consistency reliability and convergent valitidity.

Discriminant validity is related to the principle that different constructors' gauges should not correlate with height. Discriminant validity test is done by comparing the square root of AVE for the value of each construct with the correlation value between constructs in the model. Good values are shown from the square root AVE for each construct greater than the correlation between constructs in the model (Latan and Ghozali, 2016). Comparison of 
the square root value of AVE with the correlation value between constructs in the model in Figure 3 follows:

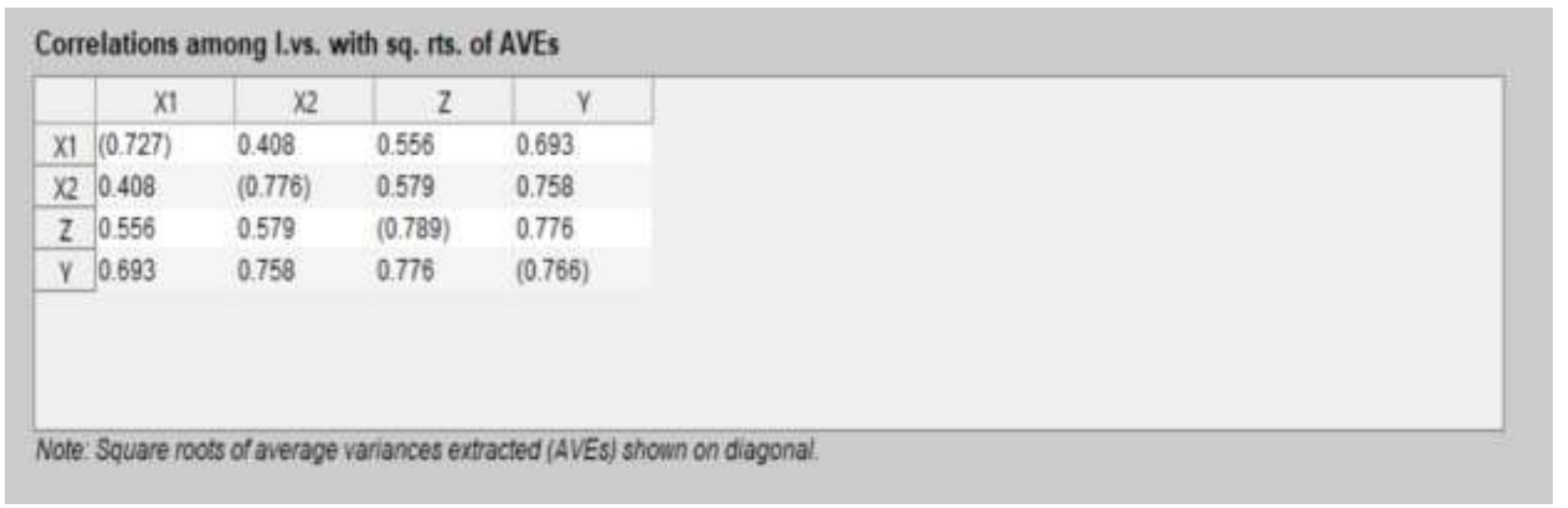

Figure 3. Comparison of AVE Square Root Value and Correlation Value between Constructions

Source: Research Results, 2020 (Data Processed)

Figure 3 shows that the AVE square root value for each construct is greater than the correlation between constructs in the model, thus the research model meets the discriminant validity criteria.

Structural model analysis (inner model), inner model analysis is done by estimating the path coefficient of the relationship between constructs. The value of the path coefficient on the relationship between variables becomes a reference in estimating. A positive value indicates a positive influence and vice versa a negative value indicates a negative effect. The greater the value of the path coefficient, the greater the influence between these variables.

The structural model of the research picture can be seen in Figure 4 below

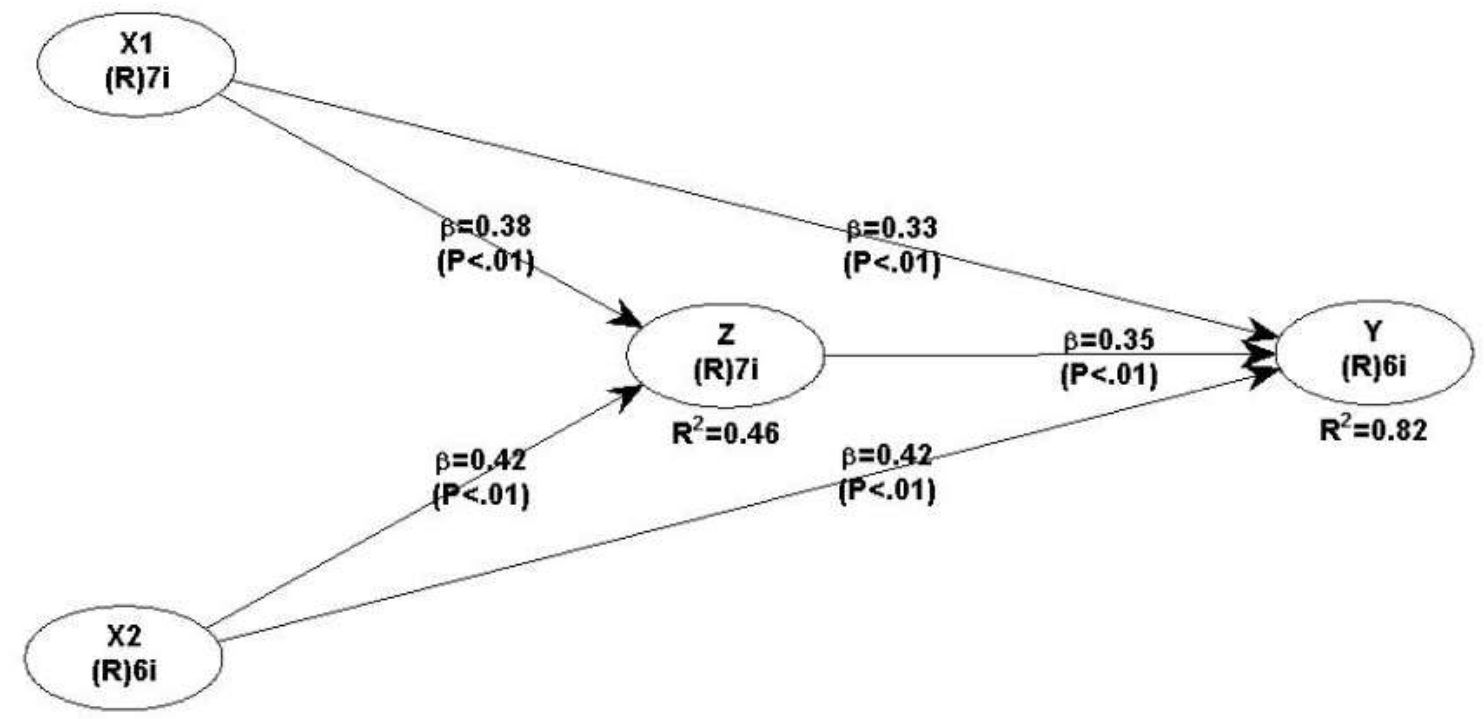

Figure 4. Structural Model

To find out the direct influence of exogenous variables on endogenous variables can be seen in table 3 as follows: 
Table 3. Direct Effects

\begin{tabular}{lc}
\hline \multicolumn{1}{c}{ Influence } & Path Coefficient \\
\hline $\begin{array}{l}\text { Emotional Intelligence Organisasi } \rightarrow \text { Organizational } \\
\text { Commitment }\end{array}$ & 0,383 \\
\hline Work Environment $\rightarrow$ Organizational Commitment & 0,423 \\
\hline $\begin{array}{l}\text { Organizational Commitment } \rightarrow \text { Employee } \\
\text { Performance }\end{array}$ & 0,350 \\
\hline Emotional Intelligence $\rightarrow$ Employee Performance & 0,326 \\
\hline Work Environment $\rightarrow$ Employee Performance & 0,423 \\
\hline
\end{tabular}

Source: Research Results, 2020 (Data processed)

In table 3 it can be seen that in forming organizational commitment, emotional intelligence and work environment give each directly a positive influence. The magnitude of the direct influence of emotional intelligence $(\xi 1)$ on organizational commitment $(\eta 1)$ is 0.383 and the magnitude of the direct influence of the work environment ( $\xi 2)$ on organizational commitment $(\eta 1)$ is 0.423 .

In shaping employee performance, emotional intelligence, work environment, and organizational commitment give each positive influence. The direct effect of emotional intelligence $(\xi 1)$ on employee performance $(\eta 2)$ is 0.326 . The amount of direct influence of the work environment $(\xi 2)$ on employee performance $(\eta 2)$ is 0.423 . The direct effect of organizational commitment $(\eta 1)$ on employee performance $(\eta 2)$ is 0.350 .

To find out the magnitude of the indirect effect of independent variables on the dependent variable through intervening variables can be seen in the following table 4:

Table 4. Indirect Effects

\begin{tabular}{lc}
\hline \multicolumn{1}{c}{ Influence } & Indirect Effects \\
\hline $\begin{array}{l}\text { Emotional Intelligence } \rightarrow \text { Employee } \\
\text { Performance }\end{array}$ & 0,134 \\
\hline Work Environment $\rightarrow$ Employee Performance & 0,148 \\
\hline Souree Research Results,
\end{tabular}

Source: Research Results, 2019 (Data processed)

Table 4 shows the indirect effect of emotional intelligence $(\xi 1)$ on employee performance $(\eta 2)$ through organizational commitment $(\eta 1)$ is 0.134 or can be calculated by multiplying the direct effect of exogenous variables on mediating variables with the direct effect of mediating variables on endogenous variables $(\xi 1 \square \eta 1) *(\eta 1 \square \eta 2)=0.383 * 0.350$ $=0.134$. The magnitude of the indirect effect of the work environment ( $\left.\xi_{2}\right)$ on employee performance $(\eta 2)$ through organizational commitment $(\eta 1)$ is 0.276 or can be calculated $(\xi 2$ $\square \eta 1) *(\eta 1 \square \eta 2)=0.423 * 0.350=0.148$.

To find out the magnitude of the effect of total independent variables on the dependent variable can be seen in the following table 5:

Table 5. Total Effects

\begin{tabular}{lc}
\hline \multicolumn{1}{c}{ Influence } & Total Effects \\
\hline Emotional Intelligence $\rightarrow$ Employee Performance & 0,460 \\
\hline Work Environment $\rightarrow$ Employee Performance & 0,571
\end{tabular}

Source: Research Results, 2020 (Data processed)

Table 5 shows the magnitude of the effect of total emotional intelligence on employee performance through mediating organizational commitment is 0.460 or can be calculated by 
adding the direct effect and indirect effect of the independent variable on the dependent variable $(\xi 1 \square \eta 2)+(\xi 1 \square \eta 1 \square \eta 2)=0.326+0.134=0.460$. The magnitude of the effect of the total work environment on employee performance through mediating organizational commitment is 0.571 or can be calculated $(\xi 2 \square \eta 2)+(\xi 2 \square \eta 1 \square \eta 2)=0.423+0.148=$ 0.571

The coefficient of determination is used to see how much influence exogenous variables have on endogenous variables, the greater the value means the greater effect. Because the number of indicators for each construct varies in number, the analysis of the coefficient of determination is done by looking at the value on the R-square. The R-square value was obtained by calculating the WarpPLS 7.0 algorithm and can be seen in table 6 .

Table 6. Coefficient of Determination

\begin{tabular}{lc}
\hline \multicolumn{1}{c}{ Variable } & $\boldsymbol{R}$ Square \\
\hline Organizational Commitment & 0,458 \\
\hline Employee performance & 0,818 \\
\hline Source: Research Results, 2020 (Data processed)
\end{tabular}

Table 6. shows that the influence of emotional intelligence and work environment together in forming organizational commitment is $45.8 \%$. The remaining $54.2 \%$ is explained by other variables outside the study.

Table 6. also shows that the influence of emotional intelligence, work environment, and organizational commitment together in shaping employee performance is $81.8 \%$. The remaining $18.2 \%$ is explained by other variables outside the study.

\section{Conclusion}

1. Emotional intelligence has a positive and significant effect on organizational commitment at PT. Berkat Bima Sentana. That is, the better the emotional intelligence of employees, the higher the organizational commitment.

2. The work environment has a positive and significant effect on the work commitments of PT. Berkat Bima Sentana. That is, the better the work environment, the higher the organizational commitment.

3. Organizational commitment has a positive and significant effect on the performance of the employees of PT. Berkat Bima Sentana. That is, the higher the organizational commitment, the higher the employee's performance.

4. Emotional intelligence has a positive and significant effect on the performance of employees of PT. Berkat Bima Sentana. That is, the higher the emotional intelligence of employees, the higher the employee's performance.

5. The work environment has a positive and significant effect on the performance of the employees of PT. Berkat Bima Sentana. That is, the better the work environment, the higher the employee's performance.

6. Emotional intelligence has a positive and significant effect on the performance of employees of PT. Berkat Bima Sentana through organizational commitment. Thus organizational commitment acts as an intervening variable that can mediate emotional intelligence with employee performance.

7. The work environment has a positive and significant effect on the performance of the employees of PT. Berkat Bima Sentana through organizational commitment. Thus organizational commitment acts as an intervening variable that can mediate the work environment with employee performance. 


\section{Suggestion}

1. It is expected that PT. Berkat Bima Sentana, it can increase the emotional intelligence of its employees, especially those related to social skills, where company management can facilitate employees with systematic and continuous emotional quotient training (EQ) to employees so that it is expected to increase employees' emotional intelligence which will later have an impact on increasing commitment employee organization and performance.

2. It is expected that PT. Berkat Bima Sentana, it can improve the work environment, especially those related to the physical work environment, one of which is by providing a more comfortable workspace with adequate lighting and air circulation so that it can increase organizational commitment that impacts on improving employee performance.

3. It is expected that PT. Berkat Bima Sentana, it can improve organizational commitment, especially those related to affective commitments such as giving awards to employees who excel, providing training and developing employees and providing feedback on employee work that is expected to have an impact on improving employee performance.

4. For further researchers, it is expected to be able to further develop theories regarding variables that are thought to have a strong relationship with purchasing decisions and add other variables aside from this research.

\section{References}

Busro, Muhammad. 2018. Teori-Teori Manajemen Sumber Daya Manusia. Jakarta: Prenadamedia Group.

Goleman, D. 2005. Kecerdasan Emosional untuk Mencapai Puncak Prestasi. Jakarta: Gramedia Pustaka Utama.

Hasibuan, Malayu SP. 2005. Manajemen Sumber Daya Manusia Edisi Revisi. Jakarta: PT Bumi Aksara

Kaswan. 2012. Manajemen Sumber Daya Manusia untuk Keunggulan Bersaing Organisasi. Yogyakarta: Graha Ilmu.

Kreitner, Robert dan Kinicki, Angelo. 2003. Perilaku Organisasi. Edisi Pertama. Jakarta: Penerbit Salemba Empat.

Latan, Hengky dan Imam Ghozali. 2016. Partial Least Squares Konsep, Metode dan Aplikasi Menggunakan Program WarpPls 5.0 (Edisi 3). Semarang: Badan Penerbit Universitas Diponegoro.

Luther, Martin Purba. 2013. Pengaruh Komitmen Organisasional, Penjualan Adaptif, Orientasi Smart-Working dan Kepuasan Hubungan Kerja TerhadapKreativitas Strategi Pemasaran Untuk Meningkatkan Kinerja Bisnis IBO Dalam Multi Level Marketing PT. Oriflame Indonesia di Medan. Tesis. Medan: Universitas Sumater Utara.

Mutimma, Riza Auda. 2016. Pengaruh Kecerdasan Emosi Terhadap Komitmen Organisasi Melalui Kepuasan Kerja Sebagai Variabel Mediasi pada Bank DKI Kantor Cabang Surabaya. Jurnal Bisnis dan Manajemen. Vol.8, No.2, pp. 156-176.

Nitisemito, Alex S. 2009. Manajemen Personalia. Jakarta: Penerbit Ghalia Indonesia.

Robbins, Stephen. P; dan Judge Timothy. A. 2015. Perilaku Organisasi. Edisi Enam Belas. Jakarta: Salemba Empat

Ronny, Yusuf Edward.2020. Manajemen Sumber Daya Manusia Sebuah Pengantar. Medan: Gerhana Media Kreasi

Ronny, Yusuf Edward \& Susanti. 2019. The Effect of Organizational Culture and Work Motivation on Employee Performance with Job Satisfaction as an Intervening Variable 
at PT. Berkat Bima Sentana. IOSR Journal of Business and Management. Vol 21, No. 3, pp. 31- 38 .

Sedarmayanti, 2011. Manajemen Sumber Daya Manusia. Reformasi Birokrasi dan Manajemen Pegawai Negeri Sipil. Bandung: Refika Aditama.

Syardiansah. (2020). The Effect of Job Satisfaction and Organizational Culture on Employee Performance of the Royal Hotel in East Aceh District. Budapest International Research and Critics Institute-Journal (BIRCI-Journal).P. 849-857

Sugiyono. 2014. Metode Penelitian Manajemen. Yogyakarta: Alfabeta.

Wahyuni, N. (2020). The Relationship between Social Supports with NursingEmployee Attachment at Dr. R.M. Djoelham Hospital Binjai. Budapest International Research and Critics Institute-Journal (BIRCI-Journal). P. 816-828.

Wowor, J. Jr., Sontje M. Sumayaku., M.O.Siwi. 2016. Pengaruh Lingkungan Kerja dan Disiplin Terhadap Komitmen Organisasional Pada Karyawan Media Cahaya Pagi. Jurnal Administrasi Publik. Vol. 3, No. 038, pp. 1 - 12. 